\title{
In vitro protein breakdown by enzyme extracts of rumen origin: comparison with methods in situ and proteases of Streptomyces griseus
}

\author{
Alejandro Velásquez ${ }^{1,2}$ and Gastón Pichard ${ }^{1}$ \\ ${ }^{1}$ Facultad de Agronomía e Ingeniería Forestal. Pontificia Universidad Católica de Chile. Vicuña Mackenna \\ 4860. Santiago, Chile. \\ ${ }^{2}$ Área de Ciencias Animales. Escuela de Agronomía. Universidad Católica de Temuco. Manuel Montt 56, \\ Temuco, Chile.
}

\begin{abstract}
A. Velásquez, and G. Pichard. 2010. In vitro protein breakdown by enzyme extracts of rumen origin: comparison with methods in situ and proteases of Streptomyces griseus. Cien. Inv. Agr. 37(3): 57-70. Proteolytic activity of enzymatic extracts generated from rumen microorganisms cultivated in vitro was evaluated. The incubation of rumen fluid used different substrates to generate a higher enzyme concentration and promote a broad spectrum of hydrolytic activity. The composition of the substrates used in the cultivation of the fluid was enriched in protein, starch or cell wall. Enzyme preparations were evaluated by incubating in $30 \mathrm{~mL}$ of buffer $50 \mathrm{mM}$ Tris- $\mathrm{HCl}(\mathrm{pH} 6.5)$ at $39^{\circ} \mathrm{C}$ during 48 hours, $100 \mathrm{mg}$ of crude protein from feeds soybean meal, canola meal, sunflower meal, gluten feed, dehydrated alfalfa meal, berseem clover, oat forage and perennial ryegrass. Enzyme extracts from cultivated rumen fluid showed an average protein breakdown of $75.5 \%$, in eight feed samples tested. This value was very close to that measured with the technique of proteases from Streptomyces griseus $(74.6 \%$ $\mathrm{CP})$, but significantly lower $(\mathrm{P} \leq 0.05)$ than the one obtained by the in situ methodology $(84.8 \%$ $\mathrm{CP})$. The technique with extracted rumen enzymes showed higher level of proteolysis in the early hours of incubation $(6 \mathrm{H})$ compared to the other techniques. These results suggest that the enzyme preparations of ruminal origin have the ability to predict degradability of feed proteins in the rumen, particularly in the first phase when most of proteins are hydrolyzed and become available for microbial utilization.
\end{abstract}

Key words: In vitro rumen proteolysis, ruminal enzymes, Streptomyces griseus, in situ method.

\section{Introduction}

Measurement of degradation dynamics of feed proteins in the rumen represents a permanent challenge to optimize the protein nutrition, in order to control the excretion of nitrogen com-

Received July 24, 2009 Accepted August 20, 2009.

Corresponding author: avelasquez@uct.cl pounds to the environment and to improve the animal welfare (Van Duinkerken et al., 2005; Kaswari et al., 2007; Riasi et al., 2008). The quantitative assessment of the breakdown process is key to carry out an effective and sustainable nutrition of the productive ruminants (Givens et al., 2000; Monteny, 2000, quoted by Van Duinkerken et al., 2005). The in situ technique developed by Mehrez and Ørskov (1977) is widely used to study the protein breakdown of the feeds in the rumen, nevertheless, several 
criticisms have weakened the merits that were originally assigned to this methodology, forcing several corrections needed to adjust the data according to their sources of error (Mathis et al., 2001; Cone et al., 2004). Research has also been developed on the proteins degradability with commercial enzymes (Pichard and Van Soest, 1977; Assoumani et al., 1992), where proteases from Streptomyces griseus fungus have been used, reaching satisfactory levels of proteins breakdown. But the use of these non ruminal proteases in in vitro conditions may result in a limited predictive value, due to uncertain enzyme-substrate specificity and the variable representation of the hydrolytic events occurring in the ruminal system (Luchini et al., 1996; Stern et al., 1997). Another methodology used to study protein breakdown in the rumen is based on the enzymatic extracts of ruminal origin (Kohn and Allen, 1995). This strategy has presented promising results; however, the reduced number of incubations, the uncertain persistence of the proteolytic activity in extracts, in addition to a probable insufficient concentration of proteases and carbohydrases, may explain why the results have not reached the expected values. It is known that the microbial consortia of the rumen degrade proteins and structural and non structural carbohydrates of feed substrates through the joint activity of carbohydrases and proteases. This may facilitate the cleavage of complex structures trapping the proteins around plant cell walls and compartments where the proteases cannot easily access (Santra and Karim, 2002; Colombatto et al., 2007). The proteolytic activity might be augmented if enzymatic extracts are obtained with a higher enzymes concentration, which will preserve an activity of broad hydrolytic range and with an adequate persistency during storage and over the incubation period. A high concentration of enzymes might be obtained by means of incubating ruminal fluid with different feed substrates, without restrictions of energetic and nitrogenous sources. This cultivation of microorganisms before the enzymes extraction would permit an adequate microbial concentration and biodiversity, allowing the generation of enzymatic preparations with a wide pool of proteases and carbohydrases, and with a subsequent improved representativeness of the ruminal proteolysis (Velásquez, 2008; Velásquez and Pi- chard, 2010). Consequently, the objective of this research was to evaluate the proteolytic activity of enzymatic extracts isolated from the ruminal fluid incubated in vitro with different substrates, as well as to compare those values with the conventional methods in situ, commercial proteases and chemical fractionation of the proteins.

\section{Materials and methods}

Enzymatic extracts were prepared from ruminal fluid incubated in vitro in batches with different substrates, so as to ensure the growth of diverse groups of ruminal microorganisms. The kinetics of proteolysis of those extracts was studied in vitro. Then, this methodological proposal was compared with techniques measuring proteins breakdown in sacco, commercial proteases (Streptomyces griseus) and chemical fractionation of feed nitrogenous compounds.

\section{Collection of rumen fluid and pre-incubation in vitro}

Ruminal fluid (RF) was collected from two adult rumen-fistulated cows, fed at maintenance level. The diet consisted on alfalfa hay $(80 \%)$ ground maize grain $(20 \%)$, mineral salts $\left(120 \mathrm{~g} \mathrm{~d}^{-1}\right)$ and free access to water; crude protein content was $14.7 \%$. The general methodology was according to Goering and Van Soest (1970). The access to feed and water was suspended one hour before the RF collection. Rumen fluid was maintained under permanent $\mathrm{CO} 2$ gassing during preparation and during the incubation period. During pre-incubation of the RF, separate flasks were supplied with different proportions of soybean meal and alfalfa meal (50/50), corn starch (Corn Starch Sigma EC 232-679-6) and ryegrass perennial cell walls NDF. Each of them was focused on microbial development with greater affinity for proteins, starches or celluloses, respectively, but always in presence of other substrates in smaller amounts, to ensure a mixed medium promoting the interactions among different types of microorganisms (Table 1). This $\mathrm{RF}$ in vitro cultivation was made with 5 grams of mixed substrates, $100 \mathrm{~mL}$ of mineral solutions, $100 \mathrm{ml}$ of sodium bicarbonate buffer $(\mathrm{pH}$ 6.8 ) with $20 \mathrm{~mL}$ of reducing solution (sodium 
sulfide at $1.25 \%$ ), $200 \mathrm{~mL}$ of distilled water and 100 mLof RF inocula. The cultivation was incubated in 2-liter-opaque flasks during 4 or 6 hours at $39^{\circ} \mathrm{C}$, under permanent $\mathrm{CO}_{2}$ gassing.

\section{Obtaining enzymatic extracts}

After pre-incubation the RF was centrifuged at $6000 \mathrm{~g}$ for 10 minutes at $4{ }^{\circ} \mathrm{C}$. The pellet was resuspended in reduced potassium phosphate buffer $50 \mathrm{mM}(\mathrm{pH} 7.1)$, containing $\mathrm{KH}_{2} \mathrm{PO}_{4}$ $50 \mathrm{mM}, 0.4 \% \mathrm{Na}_{2} \mathrm{CO}_{3}$ and $13 \mathrm{mM}\left(\mathrm{NH}_{4}\right)_{2} \mathrm{SO}_{4}$ (Nouaille et al., 2004). The cells contained in this resuspension were sonicated (SONICS Vibra Cell VC 130PB) with 4 cycles of $30 \mathrm{sec}-$ onds $(70 \mathrm{~W}, 20 \mathrm{KHZ})$ at $0{ }^{\circ} \mathrm{C}$ (Pan et al., 2003). The remaining particles and cell debris were separated from the enzymatic content by centrifugation at $15,000 \mathrm{~g}$ for 15 minutes at $4{ }^{\circ} \mathrm{C}$. The supernatant containing the enzymes was retrieved and the proteins were precipitated with ammonium sulphate saturated at $55 \%$, shaking for one hour at $0{ }^{\circ} \mathrm{C}$. Subsequently, it was centrifuged at $16000 \mathrm{~g}$ for 30 minutes at 4 ${ }^{\circ} \mathrm{C}$. The pellet was resuspended in buffer TrisHCL $50 \mathrm{mM}$ (pH 6.5), which corresponded to the raw extract of the enzymes (Karadzic et al., 2004). The enzymatic extracts were dialyzed against agar (20\%) for 24 hours, maintained at $-32{ }^{\circ} \mathrm{C}$ for one hour, then freeze dried and stored at $-32{ }^{\circ} \mathrm{C}$ until its activity was measured. This extraction from pre-incubated RF with the substrates mentioned above allowed obtaining three enzymatic concentrates, with activity preferably proteolytic $(\mathrm{P})$, amilolytic (A) and fibrolytic (F).
Test 1. Protein breakdown in vitro with ruminal enzymes

Incubation and kinetic parameters. The kinetics of protein breakdown was determined with a mixed enzymatic solution containing the three types of extracts obtained from the cultivated RF (mainly proteolytic, amilolytic or fibrolytic). The substrate evaluated were soy bean meal, canola meal, gluten feed, sunflower meal, alfalfa meal, berseem clover, perennial ryegrass and oat forage. All substrates were ground in a hammer mill to pass a $1 \mathrm{~mm}$ screen and samples containing $100 \mathrm{mg}$ of crude protein from each substrate were incubated with 100 Enzymatic Units of the extracts mixture (UE: $1 \mathrm{mg} \mathrm{CP}$ of Bovine Serum Albumin degraded hour ${ }^{-1}$, at 39 ${ }^{\circ} \mathrm{C}$ and $\mathrm{pH}$ 6.5). The enzymatic dose was structured based on 50, 25 and $25 \mathrm{UE}$, from the extracts $\mathrm{P}, \mathrm{A}$ and F, respectively. This dose was studied and calculated in previous experiments in our laboratory to ensure the first order kinetics and substrate limiting condition. These incubations were carried out during 48 hours in $125 \mathrm{~mL}$ Erlenmeyer flasks with $30 \mathrm{~mL}$ of buffer Tris- $\mathrm{HCl} 50 \mathrm{mM}(\mathrm{pH} 6.5)$ at $39{ }^{\circ} \mathrm{C}$, covered with aluminium paper. Chloramphenicol and tetracycline solution, in $0.03 \mathrm{mg} \mathrm{mL}^{-1}$ each were dosed to avoid the development of microorganisms. The flasks were frequently swirled and the test was repeated three times with duplicates for each feed sample. Incubation times were $0,1,3$, $6,12,18,24,36$ and 48 hours. The rate of hydrolysis $\left(k_{d}\right)$ and the maximum protein breakdown $\left(\mathrm{D}_{\max }, 48 \mathrm{H}\right)$ were determined. Additionally, the nitrogen fractions $\mathrm{A}, \mathrm{B}_{1}, \mathrm{~B}_{2}$ and $\mathrm{C}$ were quantified. These $\mathrm{N}$-pools represent the buffer soluble non precipitable nitrogen, the buffer soluble and

Table 1. Substrates ingredients for preincubation of rumen fluid prior to extraction of enzymes and incubation time.

\begin{tabular}{lccccc}
\hline & \multicolumn{3}{c}{ Ingredients (\%) } & & Incubation \\
\cline { 2 - 3 } \cline { 5 - 6 } $\begin{array}{l}\text { Substrate } \\
\text { Main Activity }\end{array}$ & $\begin{array}{c}\text { Corn } \\
\text { Starch }\end{array}$ & $\begin{array}{c}\text { Ryegrass } \\
\text { Cell Walls }\end{array}$ & $\begin{array}{c}\text { Soybean meal +Alfalfa } \\
\text { meal }^{1}\end{array}$ & \\
\hline Proteolytic & 10 & 40 & 50 & \\
Amilolytic & 60 & 20 & 20 & 4 \\
Fibrolityc & 5 & 75 & 20 & 6 \\
\hline
\end{tabular}

${ }^{1}$ Proportion: 50/50. 
TCA precipitable nitrogen, the insoluble degradable nitrogen compounds and the unavailable nitrogen, respectively.

Test 2. Protein in vitro_breakdown with proteases from Streptomyces griseus

Incubation and kinetic parameters. The same substrates with proteases from Streptomyces griseus (Sigma P-5147- EC 232-909-5; 4.7 UE $\mathrm{mg}^{-1}$ ) were incubated in $125 \mathrm{~mL}$ Erlenmeyer flasks, with a sample size adjusted to provide $100 \mathrm{mg}$ PC and $30 \mathrm{~mL}$ of borate-phosphate buffer at $\mathrm{pH} 7.8\left(12.2 \mathrm{~g} \mathrm{~L}^{-1} \mathrm{NaH}_{2} \mathrm{PO}_{4} \cdot 2 \mathrm{H}_{2} \mathrm{O}\right.$ and 8.91 $\mathrm{g} \mathrm{L}^{-1} \mathrm{Na}_{2} \mathrm{~B}_{4} \mathrm{O}_{7} \cdot 10 \mathrm{H}_{2} \mathrm{O}$ (Aufrère and Cartailler, 1988; Luchini et al., 1996). The enzymatic concentration in the incubation medium was 0.132 $\mathrm{UE} \mathrm{mL}^{-1}$, resulting from $12 \mathrm{~mL}$ of a protease solution with a concentration of $0.33 \mathrm{UE} \mathrm{mL}^{-1}$ and $18 \mathrm{~mL}$ of buffer borate-phosphate. All the treatments were incubated in duplicate and three repetitions were made. Other incubation conditions and kinetic calculations were described in experiment 1 .

Test 3. Protein breakdown through the in situ method

Incubation and kinetic parameters. Based on the methods described by rskov and McDonald (1979) and Pawelek et al. (2008), protein breakdown was measured in situ in the same substrates. Dacron bags $5 \times 12.5 \mathrm{~cm}$ and 50 $\pm 15 \mu$ pore size (ANKOM Technology, USA; BL101805)) were fitted in two rumen fistulated cows containing samples of $500 \mathrm{mg}$ of $\mathrm{CP}$ from each feed to be tested. The diet of these animals, as described in test 1 , was divided in 4 equal doses a day between 8:00 a.m. and 8:00 p.m. and was offered during 10 days prior to the beginning of the experiment. In this test, feeds were ground to pass a $2 \mathrm{~mm}$ screen in order to incubate larger particles and reduce physical losses from incubation bags (Ogden et al., 2006; Kaswari et al., 2007). Three bags were used per incubation time and the experiment was repeated twice. Before placing the dacron bags in the rumen, they were washed three times during 15 minutes in warm water (Roe et al.,
1991). Sampling times were $0,1,3,6,12,18,24$, 36 and 48 hours. When the bags were retrieved from the rumen, they were immediately washed with cold water $\left(7^{\circ} \mathrm{C}\right) 3$ times x 15 minutes with permanent manual shaking. Subsequently, they were dried in forced air oven at $60{ }^{\circ} \mathrm{C}$ for 24 hours. The total $\mathrm{N}$ was measured for the in sacco residue by Kjeldahl (AOAC, 1990). The particle loss corresponded to the difference between the material escaping from the bag after being washed and the fraction of soluble $\mathrm{N}$ at time zero (López et al., 1994; Hvelplund and Weisbjerg, 2000, quoted by Rotger et al., 2006). The values of protein breakdown were corrected by particle loss according to the method of Weisbjerg et al. (1996): Fraction b corrected $(b c)=b+P(b(1-$ $\left.(\mathrm{P}+\mathrm{SN}))^{-1}\right)$, where: $b$, enzymatically degraded fraction in situ (corrected in turn by microbial contamination); $\mathrm{P}$, particle loss; $\mathrm{SN}$, soluble nitrogen. Then, $\mathrm{D}_{\max }$ pool $\mathrm{A}+$ pool $\mathrm{B}_{1}+$ pool Bc. In order to correct the microbial contamination, the $\mathrm{N}$ measured (Kjeldahl) in bags incubated intra-ruminally with $500 \mathrm{mg}$ of sterile cotton fiber was discounted from the residual $\mathrm{N}$ in sacco, during the respective time, which simulated the microbial retention in situ. These bags were washed and dried as in the previous procedures, and then the kinetics parameters were calculated.

Measuring the enzymatic activity for Tests 1, 2 and 3

Protein breakdown in Tests 1 and 2 was measured as solubilised nitrogen by micro Kjeldahl (AOAC, 1990) on the total volume of incubation that was vacuum filtered (Whatman $\mathrm{N}^{\circ} 41$ paper). Digestion was carried out at $350^{\circ} \mathrm{C}$ with sulphuric acid (98.3\%) at a rate of $2 \mathrm{ml}$ per 0.5 $\mathrm{mL}$ sample of this soluble $\mathrm{N}$ phase, plus $0.01 \mathrm{~mL}$ of hydrogen peroxide $\left(\mathrm{H}_{2} \mathrm{O}_{2}\right)$. After digestion, the volume from each tube was recorded and nitrogen was colorimetrically measured by the method of Chaney and Marbach (1962), reading absorbance at $625 \mathrm{~nm}$ in a spectrophotometer (METERTEK SP-830). For Test 3, the residual in sacco $\mathrm{N}$ was measured by completely digesting the dacron bags and residue at $350^{\circ} \mathrm{C}$ during 3 to 4 hours. In order to determine the pool nitrogen fractions $\mathrm{A}$ and $\mathrm{B}_{1}$ (Tests 1, 2 and 3) 
the soluble $\mathrm{N}$ was measured at time zero, TCA soluble nitrogen and TCA precipitable nitrogen, respectively.

\section{Test 4. Chemical fractionation of the proteins}

The substrates evaluated in this research were subjected to a chemical fractionation of the nitrogenous fractions according to the methodology developed by Sniffen et al. (1992). The nitrogen fractions were grouped as Pool A, being buffer and TCA soluble N (NPN); Pool $\mathrm{B}_{1}$, buffer soluble TCA insoluble proteins; Pool $\mathrm{B}_{2}$, buffer insoluble but neutral detergent (ND) soluble nitrogen; Pool $\mathrm{B}_{3}$, ND insoluble $\mathrm{N}$ but soluble in acid detergent $\left(\mathrm{B}_{3}=\mathrm{NDF}-\mathrm{N}-\mathrm{ADF}-\mathrm{N}\right)$ and Pool $\mathrm{C}$, unavailable protein as insoluble in acid detergent (ADF-N). The maximum protein breakdown $\left(\mathrm{D}_{\text {max }}\right)$ was calculated adding up the fractions $\mathrm{A}, \mathrm{B}_{1}, \mathrm{~B}_{2}$ and $\mathrm{B}_{3}$. These $\mathrm{N}$-pools were calculated from the chemical composition of the feed substrates (Table 2).

\section{Chemical composition of the feed substrates to be incubated}

Chemical analyses were performed on dehydrated samples of soy bean meal, canola meal and sunflower meal, which were all extracted with a solvent; maize gluten feed, alfalfa meal, berseem trefoil, perennial ryegrass and oat forage. Analyses included dry matter (DM), ashes (Ash), crude protein $(\mathrm{CP})$ according to the methods described in AOAC (1990); the contents of plant cell wall (NDF) and lignocelullose (ADF) according with Van Soest et al. (1991); the true protein (TP) was estimated as insoluble $\mathrm{N}$ plus TCA insoluble fraction of the buffer soluble N, as described by Pichard and Van Soest (1977). The N fractions associated to the wall cell (NDF-N) or the lignocelullose (ADF-N) were analyzed with Kjeldahl (AOAC, 1990) on the fibrous residues (Table 2).

\section{Statistical analysis}

The proteolysis rate $\left(k_{d}\right)$, was determined by single linear regression in the exponential phase of the proteins breakdown curves $(\ln y=a-b x)$, where " $y$ " corresponded to the percentage of $\mathrm{CP}$ enzymatically degraded, " $b$ " to the fractional rate of hydrolysis $\left(k_{d}\right)$ at " $x$ " time of incubation. The kinetic curves were fitted with non linear regressions by iteration, using the computer programs SAS System Version 8 (1999) and CurveExpert Version 1.38 (2001). The parameters $\mathrm{D}_{6 \mathrm{H}}, \mathrm{D}_{\max }$ (48 hours) were determined by measuring the protein proportion degraded at 6 and 48 hours of incubation. The lag times were calculated according to the methodology pro-

Table 2. Chemical composition of feed substrates.

\begin{tabular}{|c|c|c|c|c|c|c|c|c|c|}
\hline \multirow{3}{*}{$\begin{array}{l}\text { Substrate } \\
\text { Soybean meal }\end{array}$} & \multirow{3}{*}{$\begin{array}{c}\mathrm{DM}^{1} \\
\% \\
93.59\end{array}$} & Ash & NDF & $\mathrm{ADF}$ & \multirow{3}{*}{$\begin{array}{c}\mathrm{CP} \\
47.19\end{array}$} & $\mathrm{TP}$ & \multirow{2}{*}{$\mathrm{SN}$} & \multirow{2}{*}{$\begin{array}{l}\text { NDF-N } \\
P\end{array}$} & \multirow{2}{*}{ ADF-N } \\
\hline & & \multicolumn{3}{|c|}{$\% \mathrm{DM}$} & & & & & \\
\hline & & 7.41 & 13.82 & 4.84 & & 86.07 & 23.19 & 9.42 & 5.54 \\
\hline Canola meal & 94.79 & 5.30 & 23.77 & 15.33 & 31.64 & 87.34 & 20.43 & 11.78 & 6.48 \\
\hline Maize gluten feed & 91.91 & 6.06 & 42.01 & 10.07 & 22.49 & 91.62 & 15.27 & 8.72 & 3.70 \\
\hline Sunflower meal & 93.42 & 8.38 & 32.29 & 18.20 & 35.00 & 91.42 & 20.00 & 7.68 & 4.77 \\
\hline Alfalfa meal & 91.69 & 12.43 & 38.07 & 25.06 & 20.79 & 90.19 & 12.30 & 21.10 & 12.36 \\
\hline Berseem clover & 92.69 & 13.46 & 36.08 & 16.84 & 22.49 & 89.41 & 12.70 & 21.22 & 10.71 \\
\hline Ryegrass & 93.14 & 13.08 & 58.13 & 32.63 & 10.48 & 94.22 & 7.64 & 33.89 & 18.70 \\
\hline Oat forage & 91.47 & 11.78 & 48.98 & 28.11 & 11.19 & 93.67 & 8.11 & 31.53 & 20.58 \\
\hline
\end{tabular}

${ }^{1} \mathrm{DM}$, dry matter; NDF, neutral detergent fiber; ADF, acid detergent fiber; $\mathrm{CP}$, crude protein; TP, true protein; SN, soluble N; NDF-N, insoluble nitrogen in neutral detergent fiber; ADF-N, insoluble nitrogen in acid detergent fiber. 
posed by Waldo et al. (1972), by the relation: lag $=Z * k_{d}^{-1}$, where $Z$ corresponded to the expression $a$-ln100, which represents the difference between the intercept in the axe $y$ at time $0(a)$ and the natural logarithm of the non-hydrolyzed residue at time 0 . The comparative analysis of the methodologies was based on the contrast of the kinetic parameters $\mathrm{D}_{6 \mathrm{H}}, \mathrm{D}_{\max }(48 \mathrm{H})$ and $k_{d}$. For this purpose, the validation method proposed by Freese (1960) was used as quoted by Barrales et al. (2004). In this inference test, the usual $\chi^{2}$ test of goodness of fit was used $(\mathrm{P} \leq 0.05)$. Tests 1 and 2 were repeated three times with duplicate, the experiment 3 was repeated twice with triplicates. The statistical analyses were made with the software Statistical Analysis System (1999) and SYSTAT 11 (2003).

\section{Results}

Test 1. Protein breakdown in vitro with ruminal enzymes

The highest extent of proteolysis at $48 \mathrm{H}$ was $85.5 \%$ followed by $82.6 \%$ in soy bean meal and sunflower meal respectively. The lowest values were observed in the substrates oat forage and maize gluten feed, being $68 \%$ (Table 3). The oc- currence of a lag time was not observed in the dynamics of proteins breakdown, probably due to the immediate availability and contact of the enzymes with the substrate, which do not require to be induced and secreted by microorganisms, and also due to the small particle size of the ground samples which facilitates a fast wetting and provides extensive surface for enzymes to work.

The fractional rate of protein breakdown $\left(k_{d}\right)$ was highest in perennial ryegrass and oat forage, 10.1 and $7.2 \% \mathrm{H}^{-1}$, respectively. The lowest values were observed in maize gluten feed $(5.1 \%$ $\left.\mathrm{H}^{-1}\right)$ and in canola meal $\left(6.4 \% \mathrm{H}^{-1}\right)$. Legume species, alfalfa, berseem clover and soy bean meal showed $k_{d}$ values for protein breakdown of $8 \%$ $\mathrm{H}^{-1}, 6.7 \% \mathrm{H}^{-1}$ and $6.6 \% \mathrm{H}^{-1}$, respectively.

\section{Test 2. Protein breakdown in vitro with proteases from Streptomyces griseus}

Soy bean meal and sunflower meals exhibited the highest extent of protein breakdown with Proteases from Streptomyces griseus, $84.5 \%$ and $82 \%$, respectively. The lowest values were obtained in perennial ryegrass $(67.5 \% \mathrm{CP})$ and oat forage $(65.9 \%$ CP) (Table 4). Proteolysis rates ranged from $\left(7.7 \% \mathrm{H}^{-1}\right)$ in perennial ryegrass to $5.3 \%$

Table 3. In vitro protein breakdown by ruminal enzymes ${ }^{1}$

\begin{tabular}{|c|c|c|c|c|c|c|c|c|}
\hline \multirow[b]{3}{*}{ Substrate } & \multicolumn{8}{|c|}{ Kinetic parameters } \\
\hline & \multicolumn{2}{|c|}{$k_{d}^{2}$} & Pool A & Pool B1 & Pool B2 & Pool C & $\mathrm{D}_{\max }$ & \multirow[b]{2}{*}{$\mathrm{SD}_{\text {Dma }}$} \\
\hline & $\left(\% \mathrm{H}^{-1}\right)$ & $\mathrm{SD}_{\mathrm{kd}}$ & & & $(\% \mathrm{CP})$ & & & \\
\hline Soybean meal & 6.6 & 0.08 & 14.89 & 8.82 & 61.87 & 14.42 & 85.58 & 1.130 \\
\hline Canola meal & 6.4 & 0.13 & 12.81 & 7.75 & 57.99 & 21.45 & 78.55 & 1.253 \\
\hline Maize gluten feed & 5.1 & 0.09 & 8.12 & 7.37 & 52.16 & 32.35 & 67.65 & 1.507 \\
\hline Sunflower meal & 6.5 & 0.10 & 8.76 & 11.82 & 61.99 & 17.43 & 82.57 & 1.104 \\
\hline Alfalfa meal & 8.0 & 0.25 & 10.78 & 1.84 & 64.97 & 22.42 & 77.58 & 2.137 \\
\hline Berseem clover & 6.7 & 0.21 & 11.49 & 1.90 & 62.34 & 24.28 & 75.73 & 2.432 \\
\hline Ryegrass & 10.1 & 0.18 & 7.14 & 1.50 & 60.08 & 31.29 & 68.72 & 0.770 \\
\hline Oat forage & 7.2 & 0.32 & 7.90 & 1.63 & 58.04 & 32.43 & 67.57 & 1.624 \\
\hline
\end{tabular}

${ }^{1}$ Enzymatic dose: $100 \mathrm{UE} 100 \mathrm{mg}^{-1} \mathrm{CP}$ substrate incubated; UE: $1 \mathrm{mg}$ BSA protein degraded hour ${ }^{-1}$ at 39 ${ }^{\circ} \mathrm{C}$ and $\mathrm{pH} 6.5$.

${ }^{2} k_{d}$ : hydrolysis rate; $\mathrm{SD}_{\mathrm{kd}}$ : standard deviation; $\mathrm{D}_{\max }$ : protein breakdown at $48 \mathrm{H} ; \mathrm{SD}_{\mathrm{Dmax}}$ : standard deviation. 
$\mathrm{H}^{-1}$ in maize gluten feed. Small lag times were observed in curves of protein breakdown, not exceeding one hour. These values ranged from 0.05 $\mathrm{H}$ in soy bean meal to $0.9 \mathrm{H}$ in canola meal.

\section{Test 3. In situ protein breakdown}

Proteins from the group of oil seed meals had the greatest extent of breakdown, being 93, 91 and $89 \%$ in soy, sunflower and canola meals, respectively. The proteins from grass species, oat and ryegrass, were less degraded in 48 hours (74.3 and $75.4 \%$ ) compared to high crude protein substrates like oil seed meals. The same trend was observed in the previous in vitro tests with ruminal or fungal enzymes. However, similar to the method with rumen enzymes, the rates of enzymatic hydrolysis in forage species showed the highest $k_{d}$. The rate was the highest in perennial ryegrass $\left(11 \% \mathrm{H}^{-1}\right)$ and the lowest in alfalfa meal $\left(9.5 \% \mathrm{H}^{-1}\right)$. Lag times varied from $2.7 \mathrm{H}$ in soy bean meal to $1.6 \mathrm{H}$ in sunflower meal (Table 5).

\section{Test 4. Chemical fractionation of the proteins}

The calculated size of nitrogen pools $\mathrm{A}, \mathrm{B}_{1}, \mathrm{~B}_{2}$, $\mathrm{B}_{3}$ and $\mathrm{C}$ are presented in Table 6. Pool $\mathrm{B}_{2}$ ranged from $58.5 \% \mathrm{CP}$ in perennial ryegrass to $76 \% \mathrm{CP}$ in gluten feed. In general, these magnitudes were higher in the feed substrates rich in proteins than in forage samples. It is noteworthy, that the nitrogen $\mathrm{B}_{2}$ fraction feed was the largest single pool in all substrates evaluated. Regarding the size of pool $\mathrm{B}_{3}$, which corresponds to plant cell wall bound nitrogen, the herbage samples had much

Table 4. In vitro protein breakdown with proteases from Streptomyces griseus ${ }^{1}$.

\begin{tabular}{|c|c|c|c|c|c|c|c|c|c|}
\hline \multirow{3}{*}{ Substrate } & \multicolumn{9}{|c|}{ Kinetic parameters } \\
\hline & \multicolumn{2}{|c|}{$k_{d}^{2}$} & Pool A & \multirow{2}{*}{ Pool B ${ }_{1}$} & \multirow{2}{*}{$\begin{array}{l}\text { Pool B } \\
(\% \mathrm{CP}) \\
\end{array}$} & \multirow[t]{2}{*}{ Pool C } & \multirow[t]{2}{*}{$\mathrm{D}_{\max }$} & \multirow[b]{2}{*}{$\mathrm{SD}_{\mathrm{Dmax}}$} & \multirow{2}{*}{$\begin{array}{r}\text { Lag } \\
(\mathrm{H}) \\
\end{array}$} \\
\hline & $\% \mathrm{H}^{-1}$ & $\mathrm{SD}_{k d}$ & & & & & & & \\
\hline Soybean meal & 5.9 & 0.06 & 13.52 & 9.01 & 61.99 & 15.48 & 84.52 & 0.219 & 0.053 \\
\hline Canola meal & 5.8 & 0.05 & 12.78 & 6.66 & 56.65 & 23.91 & 76.09 & 0.119 & 0.891 \\
\hline Maize gluten feed & 5.3 & 0.04 & 8.41 & 6.47 & 56.74 & 28.38 & 71.62 & 0.266 & 0.813 \\
\hline Sunflower meal & 6.0 & 0.16 & 8.65 & 10.91 & 62.41 & 18.03 & 81.97 & 0.860 & 0.367 \\
\hline Alfalfa meal & 7.2 & 0.01 & 10.01 & 2.00 & 64.44 & 23.55 & 76.45 & 0.518 & 0.108 \\
\hline Berseem clover & 6.6 & 0.18 & 10.37 & 2.21 & 60.25 & 27.17 & 72.83 & 0.537 & 0.200 \\
\hline Ryegrass & 7.7 & 0.06 & 6.13 & 1.65 & 59.68 & 32.54 & 67.46 & 0.875 & 0.768 \\
\hline Oat forage & 7.0 & 0.06 & 6.25 & 1.60 & 58.08 & 34.07 & 65.93 & 1.067 & 0.478 \\
\hline
\end{tabular}

${ }^{1}$ Enzymatic dose: $0.132 \mathrm{UE} \mathrm{mL}^{-1}$ incubation medium; UE: mMol tyrosine $\mathrm{min}^{-1}$ released at $39^{\circ} \mathrm{C}$ with $\mathrm{pH} 6.5$. ${ }^{2} k_{d}$ : hydrolysis rate; $\mathrm{SD}_{k d}:$ standard deviation; $\mathrm{D}_{\max }:$ protein breakdown at $48 \mathrm{H} ; \mathrm{SD}_{\mathrm{Dmax}}$ : standard deviation.

Table 5. In situ protein breakdown ${ }^{1}$.

\begin{tabular}{|c|c|c|c|c|c|c|c|c|c|}
\hline \multirow[b]{3}{*}{ Substrate } & \multicolumn{9}{|c|}{ Kinetic parameters } \\
\hline & \multicolumn{2}{|c|}{$k_{d}^{2}$} & Pool A & Pool B & Pool B 2 & PoolC & $\mathrm{D}_{\max }$ & \multirow[b]{2}{*}{$\mathrm{SD}_{\mathrm{Dmax}}$} & \multirow{2}{*}{$\begin{array}{c}\mathrm{Lag} \\
(\mathrm{H})\end{array}$} \\
\hline & $\left(\% \mathrm{H}^{-1}\right)$ & $\mathrm{SD}_{k d}$ & & & $(\% \mathrm{CP})$ & & & & \\
\hline Soybean meal & 7.2 & 0.18 & 13.06 & 9.80 & 70.31 & 6.83 & 93.17 & 0.591 & 2.73 \\
\hline Canola meal & 7.0 & 0.20 & 12.95 & 7.39 & 68.75 & 10.92 & 89.08 & 1.594 & 2.32 \\
\hline Maize gluten feed & 6.6 & 0.81 & 8.92 & 6.70 & 73.20 & 11.18 & 88.82 & 1.498 & 1.99 \\
\hline Sunflower meal & 7.2 & 0.31 & 8.69 & 11.61 & 71.19 & 8.51 & 91.49 & 0.081 & 1.60 \\
\hline Alfalfa meal & 9.5 & 0.51 & 11.00 & 1.60 & 71.36 & 16.05 & 83.95 & 0.453 & 1.72 \\
\hline Berseem clover & 9.8 & 0.03 & 10.57 & 2.57 & 69.44 & 17.43 & 82.57 & 0.312 & 1.96 \\
\hline Ryegrass & 11.0 & 0.24 & 6.63 & 1.26 & 67.49 & 24.62 & 75.38 & 0.069 & 1.79 \\
\hline Oat forage & 10.5 & 0.91 & 6.70 & 1.42 & 66.16 & 25.73 & 74.27 & 0.500 & 1.72 \\
\hline
\end{tabular}

${ }^{1}$ Incubation: $500 \mathrm{mg} \mathrm{CP}$ substrate bag $^{-1}$. Corrected for particle loss according to the methodology proposed by Weisbjerg et al. (1996); Fraction b corrected $=\mathrm{b}+\mathrm{P}\left(\mathrm{b}(1-(\mathrm{P}+\mathrm{Ns}))^{-1}\right)$; b, fraction enzymatically degraded; $\mathrm{P}$, particle loss; Ns, soluble N.

${ }^{2} k_{d}$ : hydrolysis rate; $\mathrm{SD}_{\mathrm{kd}}$ : standard deviation; $\mathrm{D}_{\max }$ : protein breakdown at $48 \mathrm{H} ; \mathrm{SD}_{\mathrm{Dmax}}$ : standard deviation. 
Table 6. Chemical fractionation of proteins ${ }^{1}$.

\begin{tabular}{|c|c|c|c|c|c|c|c|c|c|}
\hline \multirow[b]{3}{*}{ Substrate } & \multicolumn{9}{|c|}{ Nitrogen fractions ${ }^{2}$} \\
\hline & Pool A & Pool B & Pool B & $\mathrm{Pool} \mathrm{B}_{3}$ & $\begin{array}{l}\text { Pools } \\
\mathrm{B}_{2}+\mathrm{B}_{3}\end{array}$ & Pool C & $\mathrm{D}_{\max }^{3}$ & \multirow[b]{2}{*}{$\mathrm{SD}_{\text {Dmax }}$} & $\mathrm{CP}^{4}$ \\
\hline & & & & $(\% \mathrm{CP})$ & & & & & $(\% \mathrm{DM})$ \\
\hline Soybean meal & 13.93 & 9.25 & 67.40 & 3.88 & 71.28 & 5.54 & 94.46 & 0.538 & 47.19 \\
\hline Canola meal & 12.66 & 7.78 & 67.78 & 5.30 & 73.08 & 6.48 & 93.52 & 0.531 & 31.64 \\
\hline Maize gluten feed & 8.38 & 6.89 & 76.01 & 5.02 & 81.03 & 3.70 & 96.30 & 0.470 & 22.49 \\
\hline Sunflower meal & 8.58 & 11.42 & 72.32 & 2.91 & 75.23 & 4.77 & 95.23 & 0.791 & 35.00 \\
\hline Alfalfa meal & 9.81 & 2.49 & 66.60 & 8.74 & 75.34 & 12.36 & 87.64 & 0.604 & 20.79 \\
\hline Berseem clover & 10.59 & 2.11 & 66.08 & 10.51 & 76.59 & 10.71 & 89.29 & 0.974 & 22.49 \\
\hline Ryegrass & 5.78 & 1.86 & 58.47 & 15.19 & 73.66 & 18.70 & 81.30 & 0.770 & 10.48 \\
\hline Oat forage & 6.33 & 1.78 & 60.36 & 10.95 & 71.30 & 20.58 & 79.42 & 0.675 & 11.19 \\
\hline
\end{tabular}

${ }^{1}$ Methodology proposed by Sniffen et al. (1992).

${ }^{2}$ Pool A, soluble $\mathrm{N}$ in buffer, not precipitable with Trichloroacetic acid (TCA); Pool $\mathrm{B}_{1}$, soluble protein in buffer, precipitable with TCA; Pool $\mathrm{B}_{2}$, buffer insoluble protein minus neutral detergent insoluble protein; Pool $\mathrm{B}_{3}$, protein insoluble in neutral detergent but soluble in acid detergent; Pool $\mathrm{C}$, protein insoluble in acid detergent.

${ }^{3} \mathrm{D}_{\max }$, maximum of protein breakdown (Pool $\left.\mathrm{A}+\mathrm{B}_{1}+\mathrm{B}_{2}+\mathrm{B}_{3}\right) ; \mathrm{SD}_{\text {Dmax }}:$ standard deviation.

${ }^{4} \mathrm{CP}$, Crude Protein.

higher proportion of $\mathrm{N}$ in that fraction than oil seed and gluten feed meals; average proportions were $4.3 \%$ and $11.3 \%$ respectively. A similar observation was found for size of pool $\mathrm{C}$, which was $5.1 \%$ and $15.6 \%$ for the same two groups of substrates. A general trend was observed to find higher size of pools $\mathrm{B}_{3}$ and $\mathrm{C}$ in samples with lower total crude protein content and higher plant cell wall content.

\section{Comparison among methodologies}

The methodology based on the ruminal enzymatic extracts (REE) was compared to the techniques proteases from Streptomyces griseus, in sacco incubation and chemical protein fractionation (CFP), whose results are shown in Table 7 and supported graphically by Figure 1. It is noteworthy that all the mathematical functions to fit the kinetic curves are statistically significant $(\mathrm{P} \leq 0.05)$. The kinetic parameters of degradation observed at six hours of incubation $\left(D_{6 \mathrm{H}}\right)$, maximum protein degradation $\left(\mathrm{D}_{\max }, 48\right.$ $\mathrm{H})$ and proteolysis rate $\left(k_{d}\right)$ were contrasted. The comparisons between levels of protein breakdown reached in early times of incubation $\left(D_{6 \mathrm{H}}\right)$ in most of the evaluated substrates, showed values substantially higher with REE than those derived from alternative techniques $(\mathrm{P} \leq 0.05)$. However, the maximum extent of proteolysis attained at $48 \mathrm{H}\left(\mathrm{D}_{\max }\right)$ were significantly lower with $\mathrm{REE}$ compared to in situ $(\mathrm{P} \leq 0.05)$ in all the feeds incubated, but not so with respect to $S$. griseus, where significant differences were not detected $(\mathrm{P} \leq 0.05)$, except for maize gluten feed. The maximum breakdown of protein, $\mathrm{D}_{\text {max }}$ $(48 \mathrm{H})$, was significantly higher $(\mathrm{P} \leq 0.05)$ than the other three methods when calculated on the basis of chemical fractionation (CFP). The $k_{d}$ values for different substrates varied from 5.1 to $11.0 \% \mathrm{H}^{-1}$ across different methods, but within substrates, a significant but much smaller variation was observed. Within oil seed meals and maize gluten feed, the difference among methods was less than $1.5 \%$ absolute value, and among herbage samples such difference was under $3.5 \%$ (Table 7). The greatest average rates were obtained with the in situ method $(8.6 \%$ $\left.\mathrm{H}^{-1}\right)$ followed by REE $\left(7.1 \% \mathrm{H}^{-1}\right)$ and $S$. griseus $\left(6.4 \% \mathrm{H}^{-1}\right)(\mathrm{P} \leq 0.05)$.

\section{Discussion}

The fundamentals of the new method being reported for proteolysis studies is the use of enzymatic extracts obtained from rumen mi- 
crobes in a way that ensures the maintenance of diverse hydrolytic activities, comparable to the mixed rumen microbial populations. The provision of diverse polysaccharidases along with proteases would enhance hydrolytic synergisms in the degradative reactions of the feed substrates, which allow increasing the release of more refractory proteins, trapped in complex interactions with structural carbohydrates in cell walls, and release low accessibility proteins, attached to starch-like complexes or trapped in hard penetration-intracellular compartments (Chamberlain and Choung, 1995; Kornegay, 1996; Hristov et al., 2008). The observations obtained from our study on kinetics of protein breakdown with ruminal enzymes are comparable to the results published by Kohn and Allen (1995), who also used the technique based on ruminal enzymes. The results observed in this research exhibit a slight superiority in relation to the results reported by these authors. For example, they obtained $47.3 \%$ of protein breakdown in soy bean meal after 16 hours of incubation; in this work we obtained 53.8\% degraded at 12 hours. In alfalfa meal we achieved $39.2 \%$ protein degradation at 12 hours and $54.2 \%$ at 18 hours; which were higher values than the result obtained by Kohn and Allen (1995), who measured 42\% degraded CP in alfalfa hay at 16 hours of incubation. Mahadevan et al. (1987), who also studied the proteins degradability using ruminal enzymatic extracts, found $25 \%$ of protein breakdown in soy bean meal in 5 hours of incubation, a

Table 7. Breakdown of proteins according to the methodologies used: ruminal enzyme extracts (REE), proteases from Streptomyces griseus, in situ and chemical fractionation of proteins (CFP)

\begin{tabular}{|c|c|c|c|c|}
\hline \multirow[b]{2}{*}{ Substrate } & \multicolumn{4}{|c|}{ Methodology ${ }^{1}$} \\
\hline & REE & S.griseus & In situ & CFP \\
\hline \multicolumn{5}{|l|}{$\overline{\mathrm{D}_{6 \mathrm{H}}{ }^{2}(\% \mathrm{CP})}$} \\
\hline Soybean meal & $41.13 \mathrm{a}$ & $39.50 \mathrm{a}$ & $32.62 b$ & - \\
\hline Canola meal & $35.77 \mathrm{a}$ & $29.83 b$ & $31.01 \mathrm{~b}$ & - \\
\hline Maize gluten feed & $33.79 \mathrm{a}$ & $24.79 b$ & $26.02 b$ & - \\
\hline Sunflower meal & $38.05 \mathrm{a}$ & $35.05 b$ & $33.66 \mathrm{~b}$ & - \\
\hline Alfalfa meal & $25.94 \mathrm{a}$ & $25.20 \mathrm{a}$ & $22.97 b$ & - \\
\hline Berseem clover & $25.83 a$ & $24.25 \mathrm{a}$ & $20.32 b$ & - \\
\hline Ryegrass & $17.58 \mathrm{a}$ & $17.34 \mathrm{a}$ & $15.90 \mathrm{~b}$ & - \\
\hline Oat forage & $18.46 \mathrm{a}$ & $17.91 \mathrm{ab}$ & $16.35 \mathrm{~b}$ & - \\
\hline Mean & $29.57 \mathrm{a}$ & $26.73 b$ & $24.86 c$ & - \\
\hline \multicolumn{5}{|l|}{$\mathrm{D}(\% \mathrm{CP})$} \\
\hline Soybean meal & $85.58 \mathrm{~b}$ & $84.52 b$ & $93.17 \mathrm{a}$ & $94.46 \mathrm{a}^{3}$ \\
\hline Canola meal & $78.56 \mathrm{c}$ & $76.09 \mathrm{c}$ & $89.08 \mathrm{~b}$ & $93.52 \mathrm{a}$ \\
\hline Maize gluten feed & $67.65 \mathrm{~d}$ & $71.62 \mathrm{c}$ & $88.82 \mathrm{~b}$ & $96.30 \mathrm{a}$ \\
\hline Sunflower meal & $82.57 \mathrm{c}$ & $81.97 \mathrm{c}$ & $91.49 \mathrm{~b}$ & $95.23 \mathrm{a}$ \\
\hline Alfalfa meal & $77.58 \mathrm{c}$ & $76.45 \mathrm{c}$ & $83.95 \mathrm{~b}$ & $87.64 \mathrm{a}$ \\
\hline Berseem clover & $75.73 \mathrm{c}$ & $72.83 \mathrm{c}$ & $82.57 \mathrm{~b}$ & $89.29 \mathrm{a}$ \\
\hline Ryegrass & $68.72 \mathrm{c}$ & $67.46 \mathrm{c}$ & $75.38 \mathrm{~b}$ & $81.30 \mathrm{a}$ \\
\hline Oat forage & $67.57 \mathrm{c}$ & $65.93 \mathrm{c}$ & $74.27 \mathrm{~b}$ & $79.42 \mathrm{a}$ \\
\hline Mean & $75.50 \mathrm{c}$ & $74.61 \mathrm{c}$ & $84.84 \mathrm{~b}$ & $89.65 \mathrm{a}$ \\
\hline \multicolumn{5}{|l|}{$\mathrm{k}_{\mathrm{d}}\left(\% \mathrm{H}^{-1}\right)$} \\
\hline Soybean meal & $6.6 \mathrm{~b}$ & $5.9 \mathrm{c}$ & $7.2 \mathrm{a}$ & - \\
\hline Canola meal & $6.4 b$ & $5.8 \mathrm{c}$ & $7.0 \mathrm{a}$ & - \\
\hline Maize gluten feed & $5.1 \mathrm{~b}$ & $5.3 b$ & $6.6 \mathrm{a}$ & - \\
\hline Sunflower meal & $6.5 b$ & $6.0 \mathrm{c}$ & $7.2 \mathrm{a}$ & - \\
\hline Alfalfa meal & $8.0 \mathrm{~b}$ & $7.2 \mathrm{c}$ & $9.5 \mathrm{a}$ & - \\
\hline Berseem clover & $6.7 \mathrm{~b}$ & $6.6 \mathrm{~b}$ & $9.8 \mathrm{a}$ & - \\
\hline Ryegrass & $10.1 \mathrm{a}$ & $7.7 \mathrm{~b}$ & $11.0 \mathrm{a}$ & - \\
\hline Oat forage & $7.2 \mathrm{~b}$ & $7.0 \mathrm{~b}$ & $10.5 \mathrm{a}$ & - \\
\hline Mean & $7.1 \mathrm{~b}$ & $6.4 \mathrm{c}$ & $8.6 \mathrm{a}$ & - \\
\hline
\end{tabular}

${ }^{1}$ REE, Ruminal enzymatic extracts; S.griseus, Proteases of Streptomyces griseus; In situ, Intraruminal incubation in sacco; CFP, Chemical fractionation of proteins.

${ }^{2} \mathrm{D}_{6 \mathrm{H}}$, Breakdown observed at $6 \mathrm{~h}$ incubation; $\mathrm{D}_{\max }$, Protein breakdown $(48 \mathrm{H}) ; k_{d}$, hydrolysis rate. ${ }^{3}$ Corresponds $\mathrm{D}_{\max }\left(\mathrm{Pool} \mathrm{A}+\mathrm{B}_{1}+\mathrm{B}_{2}+\mathrm{B}_{3}\right)$. Different letter within rows indicate significant differences by $\chi^{2}$ comparisons method $(\mathrm{P} \leq 0.05)$. 

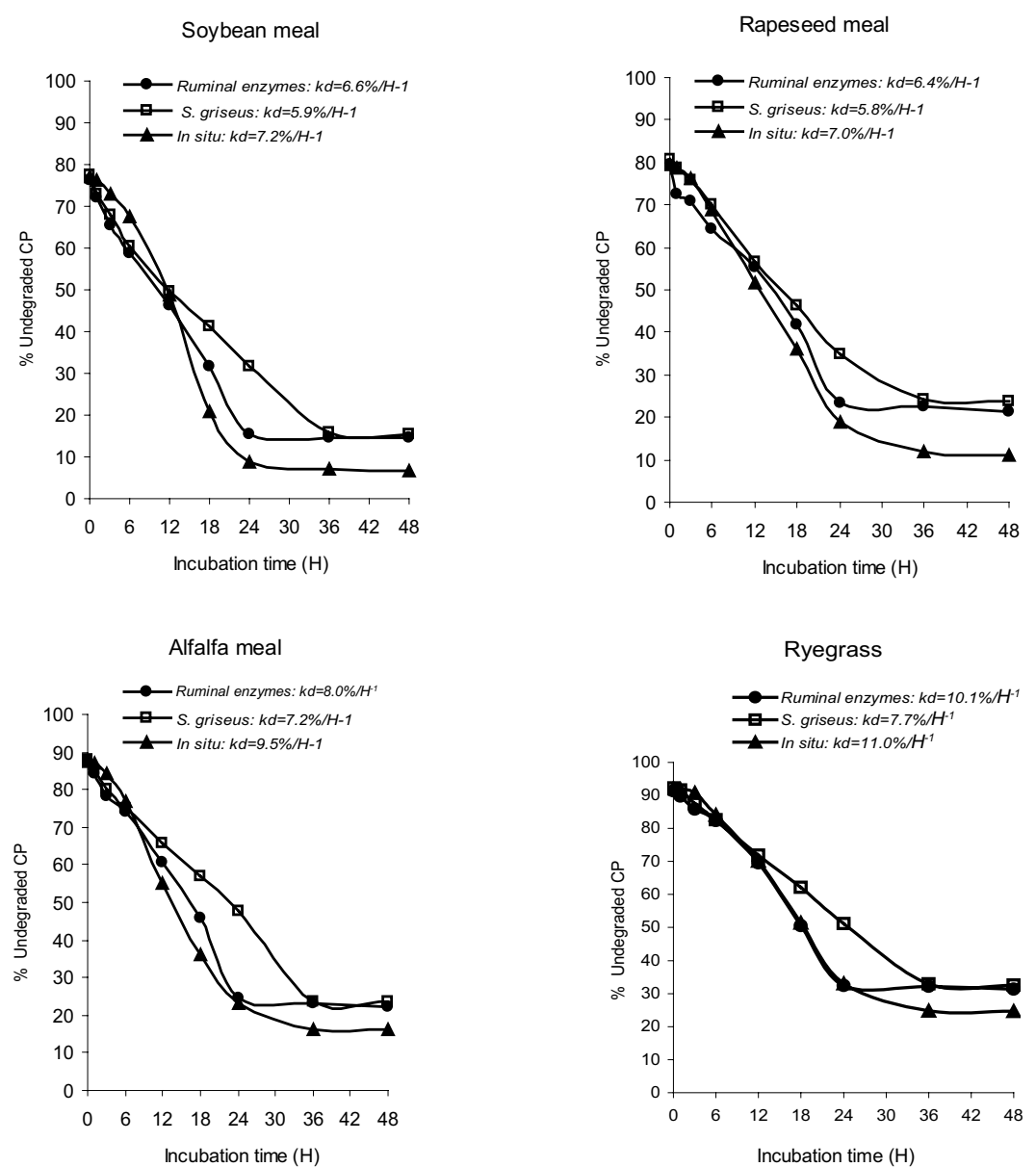

Figure 1. Protein breakdown assessed with different methodologies in soybean meal, canola meal, alfalfa meal and perennial ryegrass.

value that is substantially lower than the $34.4 \%$ protein breakdown we observed for the same feed at 3 hours of incubation. The same author measured $16.8 \%$ breakdown in soy bean meal with proteases of Streptomyces griseus after 6 hours of incubation, compared with $41 \%$ breakdown that we measured in the same substrate after 6 hours of incubation. Mathis et al. (2001), who also worked with proteases of Streptomyces griseus, obtained $76 \%$ of protein breakdown in alfalfa meal at 48 hours of incubation, similar to the $77.6 \%$ observed in this study. The rates of proteolysis $\left(k_{d}\right)$ measured in this study with ruminal extracted enzymes were in ranges comparable to the results published by Sniffen et al. (1992) and NRC (2001). For example, in soy bean meal we measured $6.6 \% \mathrm{H}^{-1}$ with enzymatic extracts; Sniffen et al. (1992) published values of 6 and $8 \% \mathrm{H}^{-1}$ and NRC (2001) reported $7.5 \% \mathrm{H}^{-1}$. In alfalfa meal a $k_{d}$ of $8 \% \mathrm{H}^{-1}$ was obtained. Sniffen et al. (1992) reported 7 and $9 \% \mathrm{H}^{-1}$ and NRC (2001) $6.7 \% \mathrm{H}^{-1}$.

One aspect that has been stressed in this new methodology is the study of early protein breakdown as key information for efficient synchrony of nitrogen and energy sources in rumen, a subject that has been pointed out by several authors (Peltekova and Broderick, 1996; Broderick et al., 2004). But such measurement is heavily influenced by the duration of initial lag time observed according with laboratory methods. In the enzymatic strategy (REE) presented here, there was essentially no lag time before the onset of the proteolysis at its specific rate constant; when using proteases of $S$. griseus, lag varied from 0.05 to 0.77 hours and the method in situ from 1.7 to 2.7 hours. Those values have a major influence when calculating the quantity of pro- 
tein released in the first 6 hours after beginning feed intake. There has been a long term discussion about the actual occurrence of lag time under in vivo rumen conditions. Some factors will undoubtedly lead to lag, like wetting time for dry feedstuffs, the need for growth of microbial mass after fasting or under feed depleted rumen status, or the need for adaptation of microflora to very different fermentable substrates. However, if access to feed is rather continuous and there is no major difference in feed composition, little argument would sustain the latter explanations. Van Soest (1991) has suggested that lag time may be an artefact much influenced by the laboratory techniques used, but that there would be no strong evidence of occurrence under in vivo rumen conditions. The dacron bags used in the in situ method have been subjected to several criticisms due to difficulty or easiness of the feed sample and microbes to enter and leave the bags across the membrane (Mathis et al., 2001; Cone et al., 2004) This may well be one reason for creating lag times during the experiments. The lack of lag time during incubation with REE should be related with a good enzymatic activity, a non limiting enzyme-substrate affinity, a high enzyme/substrate ratio, as well as being helped by the small particle size resulting from sample grinding prior to incubation.

Beyond the six hours early incubation time, the calculated rates of proteolysis with REE were not as high as under the in situ rumen method, thus bringing a question about effectiveness of the former for longer time studies. The extents of final hydrolysis were lower but still quite high, on average $75.5 \%$ compared with $84.8 \%$ in REE and in situ respectively (Table 7). There has been a general acceptance of in situ values as being correct for representing in vivo situation, and if that is true, the REE method would have to be reviewed in its potential for longer time incubation studies. However, it must be considered that most of the protein metabolism in rumen occurs much before 48 hours, thus bringing weaknesses regarding the importance of 48 hours events.

The fact that the rumen of the donor cow is fed four times a day, thus keeping a constant renewal of enzymatic power from succeeding microbial populations is in favour of the high extent of proteolysis found in situ, as compared to batch systems with no removal nor addition of any enzyme or nutrient after the onset of the incubation.

The rates of proteolysis with rumen extracted enzymes (REE) were slightly higher than with $\mathrm{S}$. griseus in several substrates $(\mathrm{P}<0.05)$, which may be favoured by the presence of a diversity of carbohydrolytic and proteolytic enzymes in the ruminal extracts, in comparison to the $\mathrm{S}$. griseus protease whose enzymatic pool is broad and based predominantly on exo and endo-proteases of fungal origin, which presents an ecological niche rather different from the complex niche in the ruminal ecosystem. There was good agreement in the maximum extent of proteolysis $\mathrm{D}_{\max }(48 \mathrm{H})$, between methods REE and $\mathrm{S}$. griseus, probably because such long time is enough for most enzymatic methods to complete hydrolysis of non refractory nitrogen compounds.

The chemical method indicates very low figures of unavailable nitrogen compared to any of the other enzymatic or in vivo methods. This is because it is estimated as acid detergent insoluble nitrogen, which yields an extremely refractory fraction linked to lignocellulose and other complex compounds which are resistant to strong chemical agents. As expected, it was found that feed substrates with higher $\mathrm{B}_{3}$ and $\mathrm{C}$ pool sizes, had the lowest potential protein degradability, which was observed across the different biological methods tested.

Consequently, the use of enzymatic preparations of ruminal origin was successful to describe the initial process of hydrolysis of the proteins. Although the extents of final breakdown were lower than the method in situ, this methodology has the potential to be applied in studies that focus on dynamics of early proteolysis of ruminant feeds.

The use of ruminal enzymatic extracts (REE) that have been freeze dried offer a simple technique that may bring great operational advantages to laboratories that determine rates and extents of protein availability of animal feeds. 


\section{Conclusions}

The extraction and further pooling of enzyme extracts obtained from microbes grown separately in media enriched with either protein, starch or cellulose, allowed to make enzymatic preparations with ample diversity of proteases and carbohydrases. These were effectively used as enzyme sources in the in vitro assessment of rumen protein breakdown kinetics. The new technique was successful in monitoring the early stages of rumen proteolysis which is the most critical phase when looking for synchrony of nitrogen and energy sources in rumen. Lag times were not observed when using rumen extracted enzymes, thus removing a factor that may confound methodological sources with errors of the actual substrate refractoriness. Rates and extent of proteolysis compared generally well with fungal proteases from Streptomyces griseus, but the maximum extent and the overall rate of proteolysis were lower than with the in situ method.

Further research should address the study of persistency of the proteolytic activity of enzyme extracts to be used in in vitro kinetic studies.

\section{Acknowledgments}

Thanks are due to Dr. Luis Barrales for valuable statistical advise and to Mr. Eduardo Leiva for laboratory assistance. This project was funded by FONDECYT Grant Nr. 1030918.

\section{Resumen}

A. Velásquez y G. Pichard. 2010. Degradación de proteína in vitro a través de extractos enzimáticos de origen ruminal: comparación con las metodologías in situ y proteasas de Streptomyces griseus. Cien. Inv. Agr. 37(3): 57-70. Se evaluó la actividad proteolítica de extractos enzimáticos generados a partir de microorganismos ruminales cultivados in vitro. Esta incubación de fluido ruminal se realizó con diferentes sustratos por separado con el objeto de generar una mayor concentración enzimática y promover un amplio espectro de actividad hidrolítica. La composición de los sustratos empleados en el cultivo del fluido fueron enriquecidos en proteínas, almidones o paredes celulares. Los preparados enzimáticos fueron evaluados incubando en $30 \mathrm{~mL}$ de buffer Tris- $\mathrm{HCl} 50 \mathrm{mM}\left(\mathrm{pH}\right.$ 6,5) a $39^{\circ} \mathrm{C}$, durante $48 \mathrm{~h}, 100$ mg de proteína cruda de los alimentos afrecho de soya, afrecho de canola, afrecho de maravilla, harina de gluten de maíz, harina de alfalfa, trébol alejandrino, ballica perenne y avena forrajera. Las enzimas ruminales mostraron una degradación promedio de $75,5 \%$ de proteína cruda, considerando los ocho alimentos. Este valor fue muy similar al medido con la técnica proteasas de Streptomyces griseus $(74,6 \% \mathrm{PC})$, pero significativamente menor $(\mathrm{P} \leq 0,05)$ al exhibido por la metodología in situ $(84,8 \%$ PC). La técnica con extractos de enzimas ruminales mostró un nivel de proteolisis superior en las primeras horas de incubación $(6 \mathrm{H})$ respecto al resto de las técnicas comparadas. Estos resultados permiten sugerir que los preparados enzimáticos de origen ruminal tienen la capacidad de predecir in vitro la degradabilidad de las proteínas de los alimentos en el rumen.

Palabras claves: Proteolisis ruminal in vitro, in situ, enzimas ruminales, Streptomyces griseus. 


\section{References}

AOAC. 1990. Association of Official Analytical Chemists. Official Methods of Analysis, $15^{\text {th }}$ Edition.Washington, DC.

Assoumani, M.B., F. Vedeau, L. Jacquot, and C.J. Sniffen. 1992. Refinement of an enzymatic method for estimating the teoretical degradability of proteins in feedstuffs for ruminants. Anim. Feed Sci. Technol. 39:357-368.

Aufrere, J., and D. Cartailler. 1988. Mise au point d'une méthode de laboratorie de prévision de la dégradabilité des protéines alimentaires des aliments concentrés dans le rumen. Ann. Zootech. 37(4)255-270.

Barrales, L., Peña, I., and P. Fernández de la Reguera. 2004. Model validation: an applied approach. Agricultura Técnica 64(1):1-12.

Broderick, G.A., P. Udén, M.L. Murphy, and A. Lapins. 2004. Sources of variation in rates of in vitro ruminal protein degradation. J. Dairy Sci. 87:1345-1359.

Chamberlain, D.G., and J.J. Choung. 1995. The importance of rate of ruminal fermentation of energy sourges in diets for dairy cows. Recent Advances in Animal Nutrition 1: 3- 27.

Chaney, A. L., and E. P. Marbach. 1962. Modified reagents for determination of urea and ammonia. Clin. Chem. 8:130-132.

Colombatto, D., F.L. Mould, M.K. Bhat, and E. Owen. 2007. Influence of exogenous fibrolytic enzyme level and incubation $\mathrm{pH}$ on the in vitro ruminal fermentation of alfalfa stems. Animal Feed Science and Technology 137:150-162.

Cone, J.W., A.H. van Gelder, A.A. MathijssenKamman, and V.A. Hindle. 2004. Rumen escape protein in grass and grass silage determined with a nylon bag and an enzymatic technique. Anim. Feed Sci. Tech. 111:1-9.

CurveExpert v.1.38. 2001. A curve fitting system for Windows. Copyrights 2001. D.G. Hyams.

Givens, D.I., E. Owen, R.F.E. Oxford, and H.M. Omed. 2000. Forage evaluation in ruminant nutrition. UK Biddles Ltd, Guildford and King's Lynn. 480 pp.

Goering, H.K., and P.J. Van Soest. 1970. Forage fiber analysis. Agric. Handbook Nr. 379. ARS, USDA Washington D.C.

Hristov, A.N., C.E. Basel, A. Melgar, A.E. Foley, J.K. Ropp, C.W. Hunt, and J.M. Tricarico. 2008.
Effect of exogenous polysaccharide-degrading enzyme preparations on ruminal fermentation and digestibility of nutrients in dairy cows. Animal Feed Science and Technology 145: 182-193.

Karadzic, I., Masui, A., and N. Fujiwara. 2004. Purification and Characterization of a Protease from Pseudomonas aeruginosa Grown in Cutting Oil. Journal of Bioscience and Bioengineering 98(3): 145-152.

Kaswari, T., P. Lebzien, G. Flachowsky, and U. Meulen. 2007. Studies on the relationship between the synchronization index and the microbial protein synthesis in the rumen of dairy cows. Animal Feed Science and Technology 139:1-22.

Kohn, R.A., and M.S. Allen. 1995. In vitro protein degradation of feeds using concentrated enzymes extracted from rumen contents. Anim. Feed Sci. Technol. 52:15-28.

Kornegay, E.T. 1996. Nutrient Management of Food Animals to Enhance and Protect the Environment. Lewis Publishers. 11: 151-165.

Lopez, S., France J., and D.K. Combs. 1994. A correction for particular matter loss when applying the polyester-bag method. Br. J. Nutr. 71:135-137.

Luchini, N.D., G.A. Broderick, and D.K. Combs. 1996. Characterization of the proteolytic activity of commercial proteases and strained ruminal fluid. J. Anim. Sci. 74: 685-692.

Mahadevan, S., J.D. Erfle, and F.D. Sauer. 1987. Preparation of protease a. from mixed rumen microorganism and its use for the in vitro b. determination of the degradability of true protein in feedstuffs. Can. J. Anim. Sci. 67:55-64.

Mathis, C.P., R.C. Cochran, E.S. Vanzant, I.E.O. Abdelgadir, J.S. Held, K.C. Olson, D.E. Johnson, J. Caton, D. Faulkner, G. Horn, S. Paisley, R. Mass, K. Moore, and J. Halgerson. 2001. A colaborative study comparing an in situ protocol with single time-point enzyme assays for estimating ruminal protein degradability of different forages. Anim. Feed Sci. Tech. 93:31-42.

Mehrez, A.Z., and E.R. Ørskov. 1977. A study of the artificial fibre bag technique for determining the digestibility of feeds in the rumen. J. Agric. Sci. 88:645-650.

Nouaille, R. Matulova, M., Delort, A. and E. Forano. 2004. Production of maltodextrin 1-Phosphate by Fibrobacter succinogenes S85. FEBS Letters 576: 226-230. 
NRC. 2001. National Research Council. The online Books Page: National Research Council Committee on Animal Nutrition, United States-Canadian Tables of Feed Composition.

Ogden, R.K., W.K. Coblentz, K.P. Coffey, J.E. Turner, D.A. Scarbrough, J.A. Jennings, and M.D. Richardson. 2006. Ruminal in situ disappearance kinetics of nitrogen and neutral detergent insoluble nitrogen from common crabgrass forages sampled on seven dates in northern Arkansas. Journal Animal Science 84:669-677.

Ørskov, E.R., and I. McDonald. 1979. The estimate of protein degradability in the rumen from incubation measurements weighed according to rate of passage. Journal of Agricultural Science (Cambridge) 92:499-503.

Pan, J., T. Suzuki, S. Koike, K. Ueda, Y. Kobayashi, K. Tanaka, and M. Okubo. 2003. Effects of urea infused into the rumen on liquid and particle associated fibrolytic enzyme activities in steers fed low quality grass hay. Animal Feed Science and Technology 104:13-27.

Pawelek, D.L., J.P. Muir, B.D. Lambert, and R.D. Wittie. 2008. In sacco rumen disappearance of condensed tannins, fiber, and nitrogen from herbaceous native Texas legumes in goats. Animal Feed Science and Technology 142:1-16.

Peltekova, V.D., and G.A. Broderick. 1996. In vitro ruminal degradation and synthesis of protein on fractions extracted from alfalfa hay and silage. J. Dairy Sci. 79:612-619.

Pichard, D.G., and P.J. Van Soest. 1977. Protein solubility of ruminant feeds. Proceedings of Cornell Nutrition Conf. Ithaca, N.Y. p. 91-98.

Riasi, A., M.D. Mesgaran, M.D. Stern, and M.J. Ruiz. 2008. Chemical composition, in situ ruminal degradability and post-ruminal disappearance of dry matter and crude protein from the halophytic plants Kochia scoparia, Atriplex dimorphostegia, Suaeda arcuata and Gamanthus gamacarpus. Animal Feed Science and Technology 141: 209-219.

Roe, M.B., L.E. Chase, and C.J. Sniffen. 1991. Comparison of in vitro techniques to the in situ technique for estimation of ruminal degradation of protein. J. Dairy Sci. 74:1632- 1640.

Rotger, A., A. Ferret, S. Calsamiglia, and X. Manteca. 2006. In situ degradability of seven plant proteín supplements in heifers fed high concentrate diets with different forage to concentrate ratio. Animal Feed Science and Technology 125:73-87.

Santra, A., and S.A. Karim. 2002. Influence of ciliate protozoa on biochemical changes and hydrolytic enzyme profile in the rumen ecosystem. Journal of Applied Microbiology 92:801-811.

Sniffen, C.J., J.D. O'Connor, P.J. Van Soest, D.G. Fox, and J.B. Russell. 1992. A net carbohydrate and protein system for evaluating cattle diets: II. Carbohydrate and protein availability. J. Anim. Sci. 70:3562-3577.

Statistical Analysis System. 1999. SAS Inst. Inc., Cary, NC, USA. SAS System Versión 8.

Stern, M.D, A. Bach, and S. Calsamiglia. 1997. Alternative techniques for measuring nutrient digestion in ruminants. J. Anim. Sci. 75:22562276.

Systat 11. 2003. SYSTAT Software Inc. (SSI). California, USA.

Van Duinkerken, G., G. André, M.C.J. Smits, G.J. Monteny, and L.B.J. Sebek. 2005. Effect of rumen degradable protein balance and forage type on bulk milk urea concentration and emission of ammonia from dairy cow houses. J. Dairy Sci. 88:1099-1112.

Van Soest, P. J., J. B. Robertson, and B. A. Lewis. 1991. Methods for dietary fiber, neutral detergent fiber, and nonstarch polysaccharides in relation to animal nutrition. J. Dairy Sci. 74:3583-3597.

Velásquez, A. and G. Pichard. 2010. Effects of rumen fluid pre-incubation on in vitro proteolytic activity of enzymatic extracts from rumen microorganisms. Animal Feed Science and Tech. 162: 75-82.

Velásquez, A. 2008. New method for the measurement of protein breakdown with ruminal enzyme extracts. Tesis Doctoral, Departamento de Ciencias Animales. Facultad de Agronomía e Ingeniería Forestal. Pontificia Universidad Católica de Chile. Santiago, Chile. 119 pp.

Waldo, D.R., L.W. Smith, and E.L. Cox. 1972. Model of cellulose disappearance from the rumen. J. Dairy Sci. 55:125-129.

Weisbjerg, M.R., T. Hvelplund, T. Hellberg, S. Olsson, and S. Sanne. 1996. Effective rumen degradability and intestinal digestibility of individual amino acids in different concentrates determined in situ. Animal Feed Science and Tech. 62:179188. 